NASA/TM—2006-214267

(245)

\title{
Accelerated Life Structural Benchmark Testing for a Stirling Convertor Heater Head
}

David L. Krause

Glenn Research Center, Cleveland, Ohio

Pete T. Kantzos

Ohio Aerospace Institute, Brook Park, Ohio 


\section{NASA STI Program . . . in Profile}

Since its founding, NASA has been dedicated to the advancement of aeronautics and space science. The NASA Scientific and Technical Information (STI) program plays a key part in helping NASA maintain this important role.

The NASA STI Program operates under the auspices of the Agency Chief Information Officer. It collects, organizes, provides for archiving, and disseminates NASA's STI. The NASA STI program provides access to the NASA Aeronautics and Space Database and its public interface, the NASA Technical Reports Server, thus providing one of the largest collections of aeronautical and space science STI in the world. Results are published in both non-NASA channels and by NASA in the NASA STI Report Series, which includes the following report types:

- TECHNICAL PUBLICATION. Reports of completed research or a major significant phase of research that present the results of NASA programs and include extensive data or theoretical analysis. Includes compilations of significant scientific and technical data and information deemed to be of continuing reference value. NASA counterpart of peer-reviewed formal professional papers but has less stringent limitations on manuscript length and extent of graphic presentations.

- TECHNICAL MEMORANDUM. Scientific and technical findings that are preliminary or of specialized interest, e.g., quick release reports, working papers, and bibliographies that contain minimal annotation. Does not contain extensive analysis.

- CONTRACTOR REPORT. Scientific and technical findings by NASA-sponsored contractors and grantees.
- CONFERENCE PUBLICATION. Collected papers from scientific and technical conferences, symposia, seminars, or other meetings sponsored or cosponsored by NASA.

- SPECIAL PUBLICATION. Scientific, technical, or historical information from NASA programs, projects, and missions, often concerned with subjects having substantial public interest.

- TECHNICAL TRANSLATION. Englishlanguage translations of foreign scientific and technical material pertinent to NASA's mission.

Specialized services also include creating custom thesauri, building customized databases, organizing and publishing research results.

For more information about the NASA STI program, see the following:

- Access the NASA STI program home page at http://www.sti.nasa.gov

- E-mail your question via the Internet to help@sti.nasa.gov

- Fax your question to the NASA STI Help Desk at 301-621-0134

- Telephone the NASA STI Help Desk at 301-621-0390

- Write to:

NASA STI Help Desk

NASA Center for AeroSpace Information 7121 Standard Drive Hanover, MD 21076-1320 
NASA/TM-2006-214267

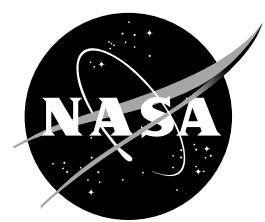

\section{Accelerated Life Structural Benchmark Testing for a Stirling Convertor Heater Head}

David L. Krause

Glenn Research Center, Cleveland, Ohio

Pete T. Kantzos

Ohio Aerospace Institute, Brook Park, Ohio

Prepared for the

Space Technology and Applications International Forum (STAIF-2006)

sponsored by the University of New Mexico's Institute for Space and Nuclear Power Studies (UNM-ISNPS)

Albuquerque, New Mexico, February 12-16, 2006

National Aeronautics and

Space Administration

Glenn Research Center

Cleveland, Ohio 44135 


\section{Acknowledgments}

The work described herein was completed with funding provided by Science Mission Directorate at NASA Headquarters. The authors thank the Glenn technical leadership and management, especially Dick Shaltens, Jeff Schreiber, Lanny Thieme, David J. Anderson, and John Sankovic, for their inspiring support and assistance. The authors also thank Gary Halford,

Randy Bowman, Vinod Arya, and Ashwin Shah for their beneficial technical collaboration, and Steve Smith and Frank Bremenour for their able laboratory support.

Trade names and trademarks are used in this report for identification only. Their usage does not constitute an official endorsement, either expressed or implied, by the National Aeronautics and Space Administration.

Level of Review: This material has been technically reviewed by technical management.

Available from

NASA Center for Aerospace Information 7121 Standard Drive

Hanover, MD 21076-1320
National Technical Information Service 5285 Port Royal Road Springfield, VA 22161 


\title{
Accelerated Life Structural Benchmark Testing for a Stirling Convertor Heater Head
}

\author{
David L. Krause \\ National Aeronautics and Space Administration \\ Glenn Research Center \\ Cleveland, Ohio 44135 \\ Pete T. Kantzos \\ Ohio Aerospace Institute \\ Brook Park, Ohio 44142
}

\begin{abstract}
For proposed long-duration NASA Space Science missions, the Department of Energy, Lockheed Martin, Infinia Corporation, and NASA Glenn Research Center are developing a high-efficiency, $110 \mathrm{~W}$ Stirling Radioisotope Generator (SRG110). A structurally significant limit state for the SRG110 heater head component is creep deformation induced at high material temperature and low stress level. Conventional investigations of creep behavior adequately rely on experimental results from uniaxial creep specimens, and a wealth of creep data is available for the Inconel 718 material of construction. However, the specified atypical thin heater head material is fine-grained with a heat treatment that limits precipitate growth, and little creep property data for this microstructure is available in the literature. In addition, the geometry and loading conditions apply a multiaxial stress state on the component, far from the conditions of uniaxial testing. For these reasons, an extensive experimental investigation is ongoing to aid in accurately assessing the durability of the SRG110 heater head. This investigation supplements uniaxial creep testing with pneumatic testing of heater head-like pressure vessels at design temperature with stress levels ranging from approximately the design stress to several times that. This paper presents experimental results, post-test microstructural analyses, and conclusions for four higher-stress, accelerated life tests. Analysts are using these results to calibrate deterministic and probabilistic analytical creep models of the SRG110 heater head.
\end{abstract}

\section{Introduction}

Under NASA's Radioisotope Power Systems project, the Department of Energy, Lockheed Martin, Valley Forge, Pennsylvania, Infinia Corporation (formerly Stirling Technology Company), Kennewick, Washington, and NASA Glenn Research Center (GRC) are developing a high-efficiency, $110 \mathrm{~W}$ electric Stirling Radioisotope Generator (SRG110) for possible use on future long-duration NASA Space Science missions including deep space missions and lunar applications (Thieme and Schreiber, 2003 and 2005). The SRG110 uses two General Purpose Heat Source (GPHS) modules as energy sources, and two Stirling cycle free-piston convertors to convert the heat energy first to mechanical and then to electrical energy. Each SRG110 Stirling convertor contains a wrought Inconel 718 (IN718) metallic heater head pressure vessel (fig. 1) that is subject to a maximum temperature of $650{ }^{\circ} \mathrm{C}$ at the hot end interface to the GPHS. This part of the heater head shell is thickened to reduce the stress level induced by internal pressure. However, one SRG110 system goal is to provide reliable operation for durations of 15 years or longer. Under these conditions, even with nominally very low stresses one important limit state for the 


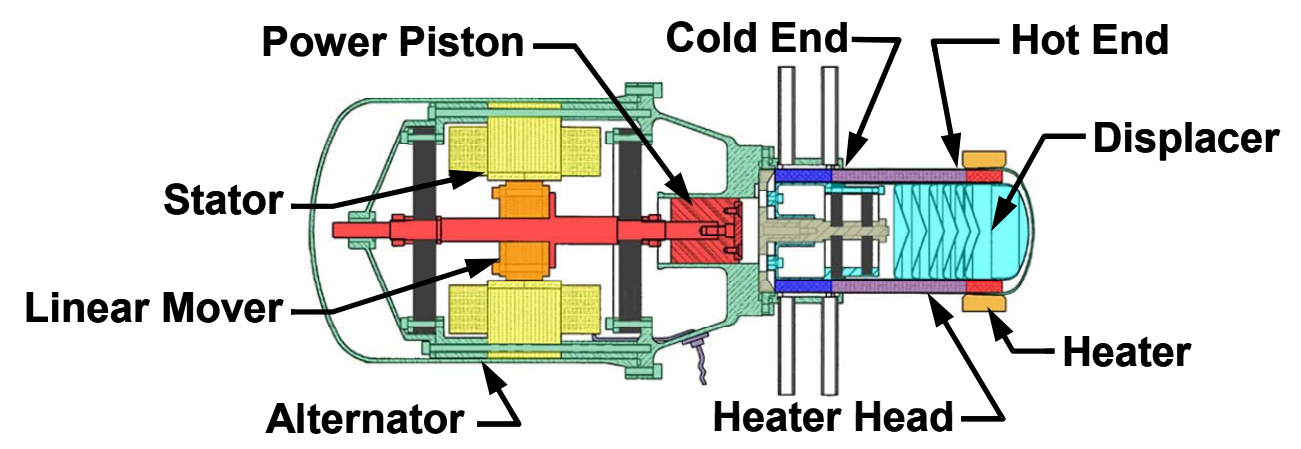

Figure 1.- Stirling convertor assembly (adapted from Schreiber and Thieme, 2003).

heater head is creep deformation. Creep is the accumulation of inelastic strain in a material under sustained loading over time. Because conventional engineering practices and available material property data were inadequate, a detailed life assessment effort is underway to accurately evaluate the heater head creep life. The objective of the heater head structural benchmark test effort is to provide experimental creep data for prototypical stress conditions for the calibration of the life assessment analytical methodologies.

\section{Stirling Convertor Heater Head Life Assessment Effort}

The Stirling convertor heater head is a variable-thickness, thin-walled cylindrical pressure vessel with an outside diameter of approximately $50 \mathrm{~mm}$. The wall is as thin as possible for heat transfer reasons and system efficiency, but thick enough to prevent high stresses from the internal $2.5 \mathrm{MPa}$ operating pressure. As a cylinder, the pressure creates a multiaxial stress field in the thin vessel wall. The field is nearly biaxial, with circumferential stress approximately twice the longitudinal stress. The open, cold end of the heater head includes an integral flange for sealing to other convertor structure; the hot end terminates with a closed, domed head. This end conducts heat from the external GPHS to an internal heat exchanger, and its metal temperature is controlled to remain at the material's maximum functional temperature of $650{ }^{\circ} \mathrm{C}$ for the most efficient machine operation. Creep resistance in the heater head wall at locations where this temperature exists is of critical importance to long life of the Stirling convertor; the life criterion for the heater head is defined as the elapsed time for creep strains to reach the onset of tertiary creep, when the creep strain rate begins rapid acceleration. Because the wall is very thin, the IN718 material is specified to be fine grain to assure bulk creep properties are not degraded by having too few grains through its thickness (Bartolotta et al., 2000; Bowman, 2001).

A four-task approach is being used to thoroughly quantify the creep resistance of the heater head under operating temperature and stress conditions (Halford et al., 2002). First, an extensive creep testing program using thin dog-bone specimens is producing uniaxial creep property data specific to the "flight" SRG110 material - an atypical fine-grained IN718 with a special heat treatment that prevents formation of two detrimental precipitates (Bowman, 2001). This task is providing previously unavailable creep deformation, creep rate, and rupture data for the IN718 alloy at stress levels from two to ten times the design principal stress.

The second life assessment task includes detailed deterministic structural analyses of the heater head using finite element analysis. Here the heater head is accurately modeled using the commercially available MARC program, and elastic and thermal stresses and strains are calculated conventionally. Creep properties derived from the test program described in the preceding paragraph are used as follows: a steady state creep rate is calculated for each test stress level and temperature by dividing the gross accumulated creep strain at the start of tertiary creep, by the elapsed time to that point; this stress, temperature, and creep rate relationship is applied to the calculated equivalent (von Mises) stresses in the finite element analysis; finally, this nonlinear analysis is run in the time domain to determine full-field 
heater head creep strains at any point in time. This method accurately predicts time to the onset of tertiary creep, which is the chosen life limit criterion. At times before this point, it generally slightly underestimates creep strains; at times over this, it grossly underestimates creep strains.

Because considerable scatter exists in creep rate and rupture information, the third task (Shah, Halford, and Korovaichuk, 2004) encompasses a probabilistic analysis of not only the test data and deterministic analyses, but also a wealth of long-term IN718 creep data generated on bulk, large-grain material (Brinkman, Booker, and Ding, 1991) for Oak Ridge National Laboratory (ORNL). In addition other convertor operating uncertainties such as variability in geometry, pressure, and temperature are accounted. This task results in the calculation of a probability of survival (PoS) to the onset of tertiary creep for the analyzed conditions. A 50 percent PoS can be interpreted as the median test data; of course, the required $\mathrm{PoS}$ for a flight unit is much higher, perhaps 99.99 percent.

\section{Structural Benchmark Testing Task}

The fourth element of the life assessment is a comprehensive benchmark testing effort (Halford et al., 2002). Under this task, heater heads and heater head-like test specimens constructed of the fine-grain IN718 alloy are tested under both prototypical and stress-accelerated conditions with real-time monitoring of surface temperatures, diametral strains, and internal pressures. Because the specimens are pressurized, an accurate biaxial stress state is imposed as in a complete Stirling convertor assembly. Test results are incorporated back into the analytical models to refine those methods if needed, and also used for an independent experimental assessment of heater head life.

The benchmark test effort includes four short-term tests: one test of a SRG110-configuration heater head test specimen, and three tests of heater head-like simplified-geometry specimens. These short-term tests use pressures greater than the design pressure to permit test results within reasonable time periods, albeit at higher than operating stress levels. Two additional long-term tests are performed on SRG110configuration heater heads using the nominal design pressure. The heater head thin wall adjacent to a transition to a thicker wall area near the hot end domed head is the gage area under study, a critical location for creep life due to its combined high temperature and relatively high stress. All benchmark tests subject this test specimen gage area to the design operating temperature of $650{ }^{\circ} \mathrm{C}$.

Because the two long-term tests are just underway at the time of this writing, no further information is presented for those tests. The remainder of this text describes the benchmark test experimental details, short-term benchmark test results, microstructural post-test analyses of test specimens, and conclusions drawn from this information.

\section{Structural Benchmark Test Experimental Details}

The main objective of the short-term benchmark tests was early observation of the circumferential secondary creep strain rate for incorporation into the life prediction analytical models. A second objective was the observation of creep strain behavior from primary, through secondary, until past the onset of tertiary creep. It was not possible to accelerate creep response by increasing test temperature, because the IN718 creep mechanism transitions above the $650{ }^{\circ} \mathrm{C}$ test temperature. Therefore, the test stress level was raised to increase creep strain rates; this was achieved by increasing the internal pressure, which served as the experimental independent variable. The dependent variable then was the heater head gage area diameter measured over time, from which diametral creep strain and rate, and time to tertiary creep were calculated. The tests were terminated prior to rupture to avoid damage to the facility.

\section{Specimen Description}

A structural analysis determined the maximum safe test pressure for the SRG110-configuration heater head based on yield at the cold-end flange. This provided the limit for available stress acceleration of

creep response. To allow even greater stresses a heater-head like test specimen was designed with reduced 
wall thickness. Table 1 provides a summary of test specimens, test conditions, and initial predictions of creep strain rate and time to the onset of tertiary creep. The SRG110-configuration specimen was manufactured by Infinia Corp., and the reduced-wall thickness specimens were fabricated by Bitec Sample Machining Inc., Dayton, Ohio. Nominal test duration was approximately the time for the specimen to reach creep rupture (except for specimen STC209). The predicted values were calculated based on the applied circumferential stress only and on creep properties derived from early experimental results of uniaxial creep testing from the first task of the life assessment effort described earlier.

TABLE 1.-HEATER HEAD STRUCTURAL BENCHMARK TEST SPECIMENS, TEST CONDITIONS, AND PREDICTIONS

\begin{tabular}{|c|c|c|c|c|c|c|}
\hline \multirow{2}{*}{$\begin{array}{l}\text { Specimen } \\
\text { ID }\end{array}$} & \multirow{2}{*}{$\begin{array}{l}\text { Nominal test } \\
\text { duration } \\
\text { (mo.) }\end{array}$} & \multicolumn{3}{|c|}{ Test conditions } & \multicolumn{2}{|c|}{ Predictions } \\
\hline & & $\begin{array}{l}\text { Hot end temp. } \\
\left({ }^{\circ} \mathrm{C}\right)\end{array}$ & $\begin{array}{c}\text { Pressure } \\
(\mathrm{MPa})\end{array}$ & Stress factor & $\begin{array}{c}\text { Creep } \\
\text { rate }\end{array}$ & $\begin{array}{c}\text { Time to tertiary } \\
\text { (days) }\end{array}$ \\
\hline Bitec1 & 1 & 650 & 7.10 & high & very high & 11 \\
\hline Bitec 2 and 3 & 3 & 650 & 6.14 & moderate & moderate & 33 \\
\hline STC209 & 6 & 650 & high & low & low & 350 \\
\hline
\end{tabular}

\section{Experimental Apparatus}

The structural benchmark testing was performed on two bench-top test rigs in a controlled laboratory environment (fig. 2). A computer-controlled closed-loop argon gas system produced accurately controlled pneumatic pressures from zero to $20 \mathrm{MPa}$. Argon was supplied by a compressed gas cylinder through small diameter stainless steel tubing. A flow meter monitored system leakage and vessel rupture. Airoperated solenoid valves provided abort capability, and air-operated regulating valves controlled test pressure at each rig. Relief valves protected the system and test specimens from accidental overpressurization. Custom loose flanges captured the test specimens' integral cold end flanges and bolted to gas manifold/mounting flanges. Ratings for all system components exceeded the pressure capability of the specimens. For personnel safety an acrylic enclosure and personnel barriers were installed.

Temperature control was provided by induction heating and a feedback temperature controller. External induction coils were used to heat the gage area to the test temperature. A conduction water cooling loop was installed at the specimen cold end to provide cooling as needed. Specimen metal temperatures were monitored by approximately twenty welded-on type $\mathrm{K}$ thermocouples. All thermocouple wire was rated for long term use at $700{ }^{\circ} \mathrm{C}$ or higher.

At each rig the gage area diameter was monitored by two diametral extensometers, placed at $90^{\circ}$ to each other in a plane perpendicular to the test specimen longitudinal axis. The extensometer resolution was $0.25 \mu \mathrm{m}$, providing a calculated strain resolution of 5 microstrain $(\mu \varepsilon)$. A bench-top extensometer drift study lasted 305 instrument-days; in general all instruments held zero strain within $0.3 \mu \varepsilon /$ day, validating the extensometers' use for long-term creep strain measurement.

The test control computer also served as the data acquisition system. For each rig data was recorded on argon pressure and leak flow, the two extensometer channels, and four gage temperatures. Rapid data recording was taken during initial test startup; long-term data acquisition occurs at a programmable frequency of once every $5 \mathrm{~min}$. Test limits produced automated aborts to the induction heater and gas system based on over- or under-pressurization, gas leakage above nominal, over- or under-temperature in the gage area, strain magnitude beyond secondary strain, or power outage greater than $10 \mathrm{~min}$. An uninterruptible power supply backed up all systems except the induction heater power supplies. 


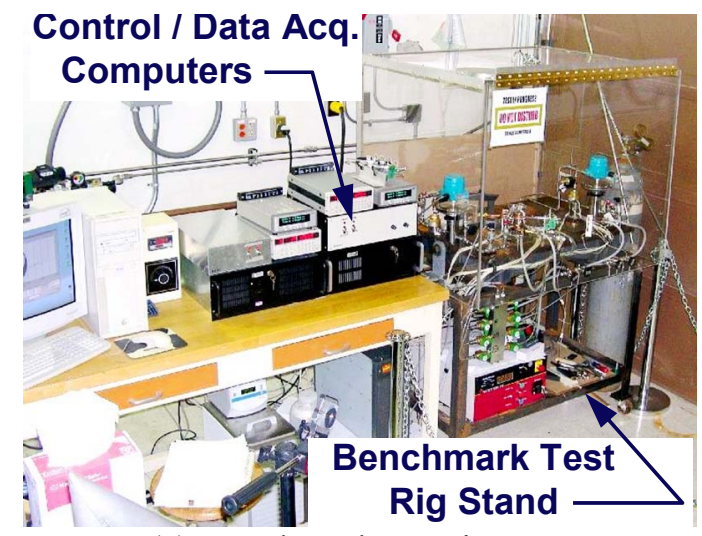

(a) Benchmark test rigs.

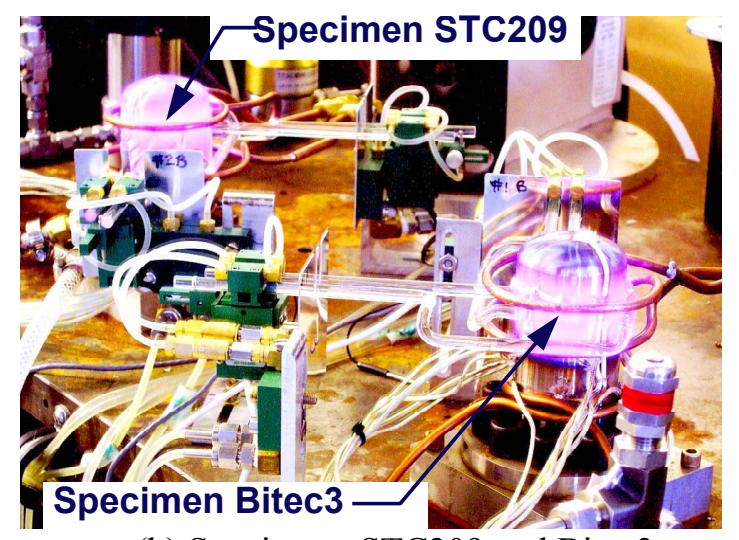

(b) Specimens STC209 and Bitec3 at test condition.

Figure 2.- Heater head structural benchmark test apparatus.

An analysis of experimental precision and sources of error was completed. This study evaluated all components of the pressure, temperature, and strain measurement systems, as well as errors in measurement of specimen geometry. The major error source in the pressure system was the pressure transducer, with a calibration accuracy of \pm 0.25 percent. For the heating system a $2{ }^{\circ} \mathrm{C}$ error was possible, attributable to the inherent properties of type $\mathrm{K}$ thermocouples. As described previously, extensometer drift was the major source of error in strain measurement. Finally, error in the measurement of specimen wall thickness resulted in 3.0 percent uncertainty in stress for the thin-wall heater head-like specimen, and 1.3 percent uncertainty for the SRG110-configuration specimen.

\section{General Test Procedures}

Prior to the start of benchmark testing for a specimen, elastic strain in the heater head specimen gage area was measured at room temperature for the test pressure. Following depressurization, the thermal expansion strain was measured for the test temperature. Then while at temperature, the data acquisition system was started and the specimen internal pressure ramped back up to the desired test pressure. The test was monitored continuously until a creep strain versus time plot clearly showed a transition to tertiary creep, or in the case of specimen STC209, the planned test duration was achieved. Following this, the pressure and heating systems were shut down, the specimen demounted, final specimen geometry measurements made, and metallurgical analysis of the specimen performed.

\section{Structural Benchmark Test Results}

Short-term, accelerated structural benchmark tests were completed successfully for IN718 heater head specimens at three stress levels. Induction heating coils were developed to provide the uniform gage area temperature of $650{ }^{\circ} \mathrm{C}$, with peak temperature less than $670{ }^{\circ} \mathrm{C}$ in the thickened domed head area, and all temperatures elsewhere less than the gage area temperature. These conditions promoted the greatest creep strain rate in the gage area, where strains were continuously monitored. At the start of testing the standard deviation of thermocouples readings was approximately $3{ }^{\circ} \mathrm{C}$ but in some cases degraded over the test duration to $6{ }^{\circ} \mathrm{C}$, for thermocouples spaced circumferentially in the gage area. A typical temperature longitudinal profile for a specimen is shown in figure 3 . 


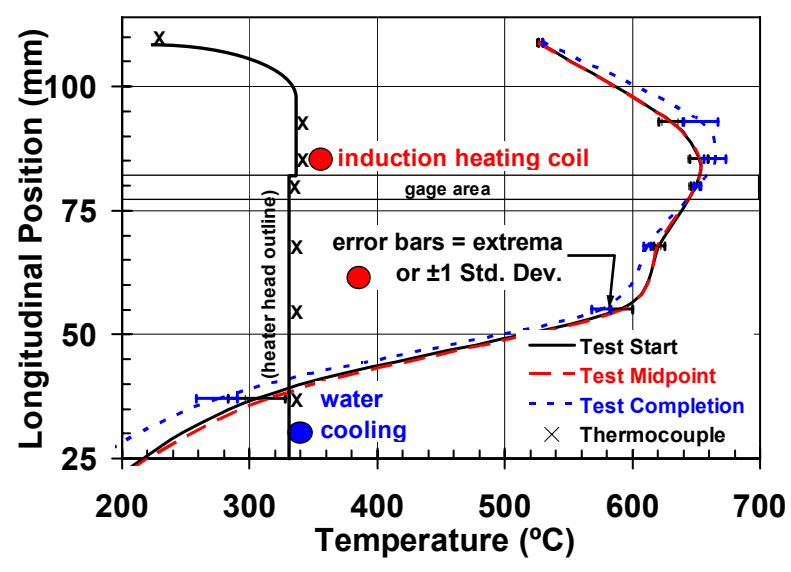

Figure 3.-Typical heater head specimen temperature profile (6-month test specimen shown).

As described earlier, the nominal one- and three-month tests used special thin wall heater head-like specimens, while the nominal six-month test used a specimen with the SRG110 geometry. The primary measurement was the specimen gage area diameter, taken by two diametral extensometers located at $90^{\circ}$ apart on the circumference; diametral strain was calculated as that measured diameter divided by the original gage diameter. The important calculated quantity of creep strain rate was determined at any point in time by the slope of the strain versus time curve for the previous seven days using linear regression.

\section{One-and Three-Month Tests}

The nominal one-month test using thin wall heater head-like specimen Bitec1 ran without incident until manually shutdown at 30 days when tertiary creep was evident. Although creep strain accumulated very uniformly, this was not as evident in the creep strain rate plot (fig. 4(a)). The minimum observed creep rate was approximately 50 percent of the expected value based on uniaxial creep testing. The two extensometer readings resulted in creep rates differing by 20 to 25 percent. The general shape of the creep rate plot indicates that little steady state, secondary creep occurred at this relatively high stress; rather, primary creep abated to a minimum creep rate that very quickly accelerated to tertiary creep.

The nominal three-month test using thin wall specimen Bitec3 was chronologically the first test accomplished. Prior to the start of testing, in the un-pressurized state this specimen endured extensive heating trials while developing an acceptable induction heating coil. It is possible that short unrecorded temperature spikes well above $650{ }^{\circ} \mathrm{C}$ in the gage area as well as towards the cold end occurred. The specimen produced a creep rate curve with a minimum creep rate nearly four times the expected value (fig. 4(b)). The difference in extensometer readings produced creep rates that varied by 180 percent. Like the one-month test, rapid acceleration followed the minimum rate. A disabled alarm-shutdown permitted the specimen to rupture, whereupon high argon flow shutdown the test.

Because the results from Bitec 3 differed greatly from predictions, a repeat of the test was performed using specimen Bitec2 (fig. 4(b)). In this case, results were less abrupt, but the minimum creep rate was nevertheless 50 percent higher than predicted. Here, the two strain recordings resulted in creep rates 300 percent apart. To investigate the cause, several configuration variables were changed consecutively: the specimen was axially rotated, the induction heating coil was repositioned, and the extensometer positions were switched. In every case the creep rate was coincident with the specimen geometry, leading to the conclusion that the creep rate inequality was a property of the specimen itself. 


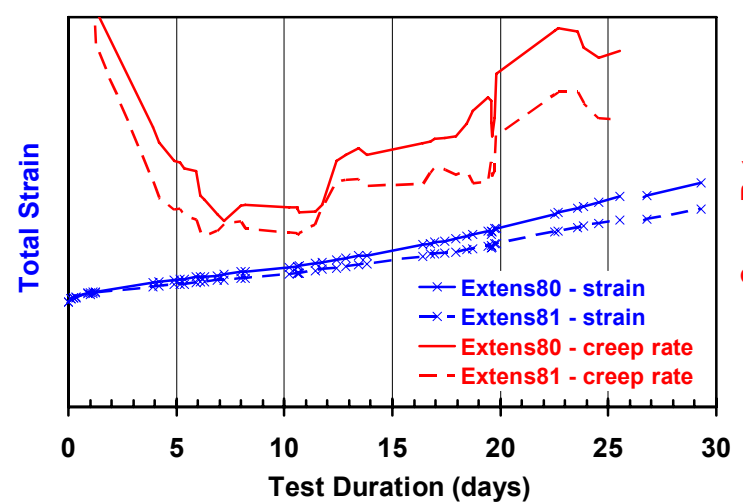

(a) Strains and creep rates for one-month test.

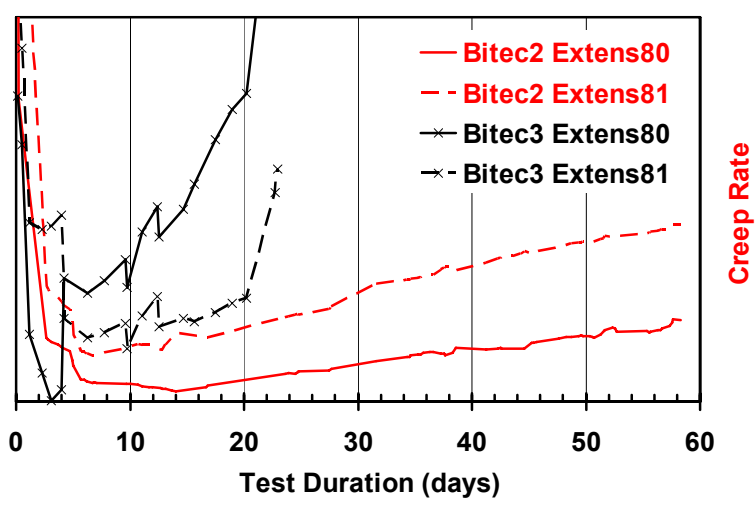

(b) Creep strain rates for three-month tests.

Figure 4.-Experimental results for one-and three-month tests.

\section{Six-Month Test}

The nominal six-month test using SRG110 heater head specimen STC209 ran a total of 131 days until manually shut down. Creep strain accumulated uniformly, increasing during the last 30 days (fig. 5). The minimum creep rate observed was one-half the predicted value. The creep rate varied within 50 percent of the prediction until the 107th day, demonstrating fairly steady-state secondary creep behavior.

\section{Post-Test Analysis}

The large variability in results for the four higher-stress, short-term benchmark tests is indicative of the large scatter commonly found in creep properties of materials, even under highly controlled laboratory environments. The three heater head-like specimens produced creep curves with no well-defined secondary creep regime. They gave minimum creep rates both below and greatly above the expected values. Even under identical test conditions for the two, three-month tests, a large difference was observed in creep response. However, these three specimens were fabricated with larger machining tolerances and less specification and control of their heat treatment. Furthermore, greater scatter can be expected when testing specimens with larger test volume than conventional standardized test specimens. Figure 6 shows specimen Bitec 3 demounted after testing; rupture area bulges are clearly evident at the position of the lower induction heating coil, even though sub-critical temperatures were recorded there. The nominal six-month test specimen exhibited creep behavior close to the predicted response for over 100 days, but tertiary creep began somewhat early; this specimen had greater controls on its fabrication and heat treatment. Figure 6 also shows a small creep bulge (at the black arrow) in the area of the lower induction heating coil for specimen STC209.

\section{Microscopy and Microstructural Investigation}

Although there is evidence that some of the premature creep deformation (bulging) may have been associated with possible hot spots, a microstructural analysis was performed to determine whether any intrinsic microstructural variables existed that could explain the observed large variability in creep rate. Specimen Bitec3, which experienced premature rupture, was systematically sectioned and polished. In general, the microstructure was typical for the material (fig. 7). Grain size was approximately $15 \mu \mathrm{m}$ and typically very uniform throughout the part. 


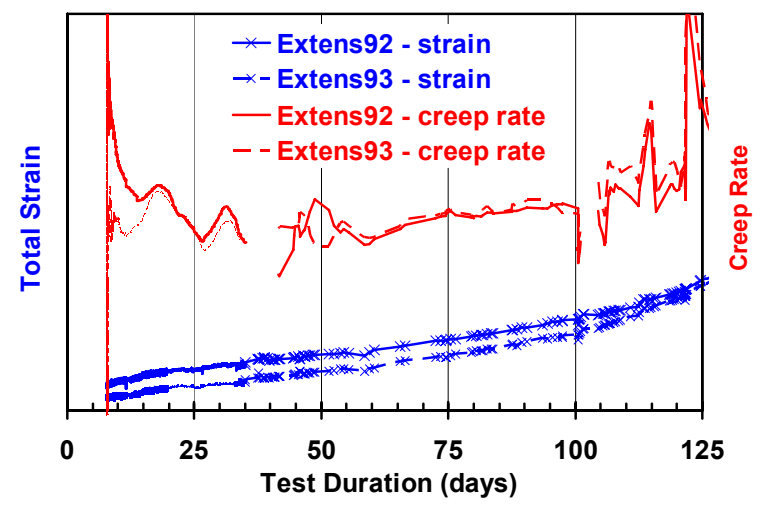

Figure 5.-Experimental results for six-month test.
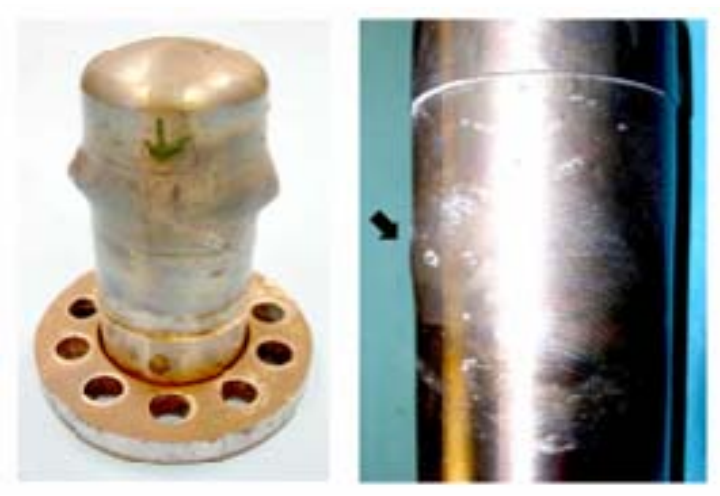

Figure 6.-Post-test photographs of specimen Bitec3 (L) and specimen STC209 (R).
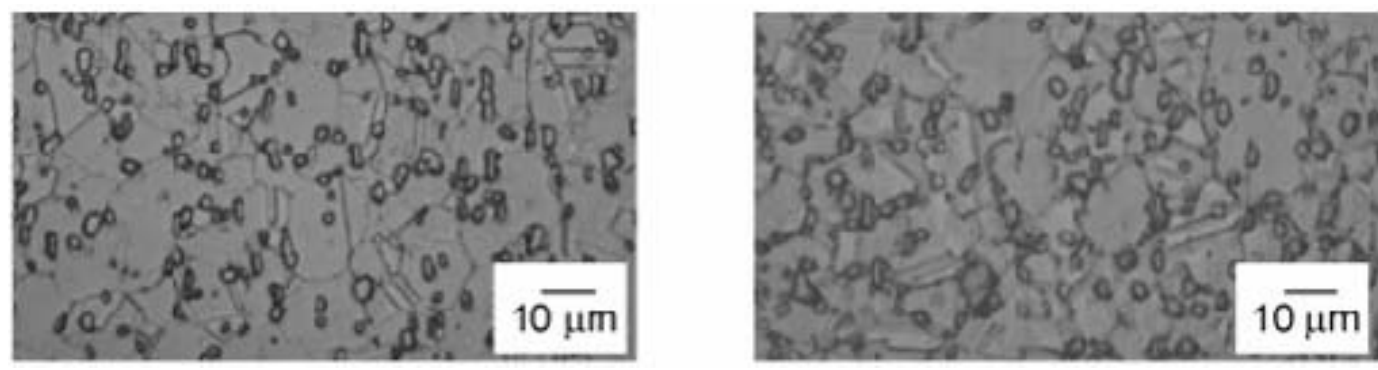

(a) Cold end unchanged from untested material. (b) Hot end shows some coarsening.

Figure 7.-Post-test optical micrographs of heater head-like specimen Bitec3. 
Further examination of the processing variables revealed some inconsistency in the cooling rates between the various materials. The baseline creep specimens were machined from the bar stock and heat treated as specimens. These specimens, $0.05 \mathrm{~cm}$ thick, were air cooled resulting in cooling rates in excess of $220^{\circ} \mathrm{C} / \mathrm{min}$. The SRG110 heater head specimens were machined to their final thin dimension and heat treated individually in an argon quench furnace resulting in somewhat slower cooling rates. The Bitec heater heads were rough machined, approximately $10 \mathrm{~mm}$ thick, and batch heat treated in an argon backfill furnace. As a result, these specimens had even slower and more variable cooling rates, in the range of 10 to $20^{\circ} \mathrm{C} / \mathrm{min}$. Since the aging was identical for all materials, faster cooling rates would result in stronger and more creep resistant material. The observed variability may therefore reflect the differences in fabrication and heat treatment. In order to confirm the effect of cooling rate variations, further evaluation of the precipitate microstructure is underway.

\section{Conclusions}

Four heater head short-term structural benchmark tests were completed as part of the Stirling convertor heater head life assessment effort for the SRG110 program. The tests applied prototypical temperature fields to the specimens, and creep results were accelerated with higher-than-operating pressures. In general, creep response was proportional to stress but varied widely from predicted mean values (fig. 8(a)). A measure of this variability can be made by comparing the experimental minimum creep rates with an unmodified probabilistic assessment of secondary creep rates drawn from the ORNL database and from the limited amount of GRC uniaxial creep testing. As shown in figure 8(b), all four benchmark tests fall within the 99.9 percent probability of survival curve (approximately three standard deviations). As described previously, the heater head life assessment deterministic and probabilistic analyses are incorporating the benchmark test results to increase the analyses' fidelity. The two remaining long-term benchmark tests will further supplement the analyses as well as independently assess heater head's mean life.

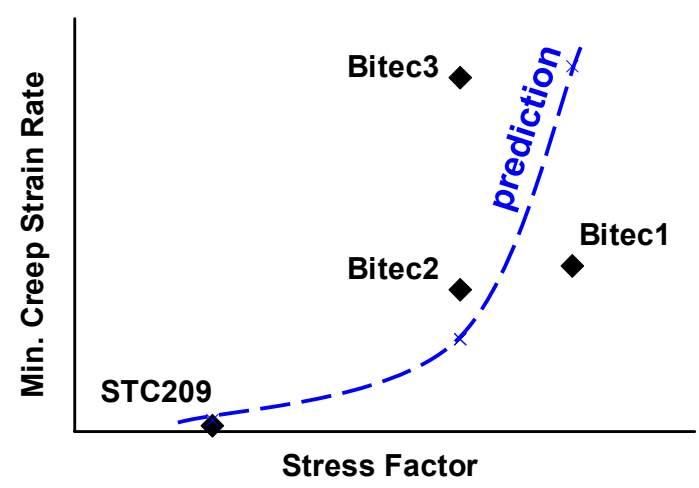

(a) Experimental creep rates versus prediction.

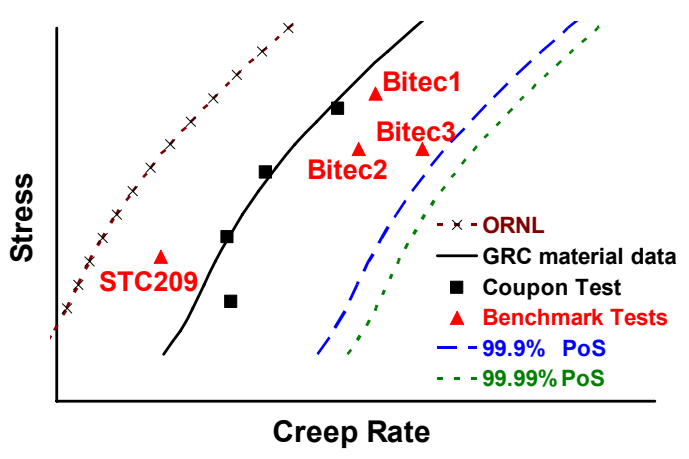

(b) Probabilistic assessment of creep rates (Shah, Halford, and Korovaichuk, 2004).

Figure 8.- Summary of heater head structural benchmark test results. 


\section{References}

1. Brinkman, C.R., Booker, M.K., and Ding J.L., "Creep and Creep-Rupture Behavior of Alloy 718," in Superalloys 718, 625, and Various Derivatives, edited by E.A. Loria, The Minerals, Metals \& Materials Society, Warrendale, PA, 1991, pp. 519-536.

2. Bartolotta, P.A., Bowman, R.R., Krause, D.L., and Halford, G.R., "Long-Term Durability Analysis of a 100,000+ Hr Stirling Power Convertor Heater Head," in Proceedings of 35th Intersociety Energy Conversion Engineering Conference and Exhibit 2000 (IECEC), Vol. 1, AIAA-2000-2841, 2000, pp. 259-265.

3. Bowman, R.R., "Long-Term Creep Assessment of a Thin-Walled Inconel 718 Stirling PowerConvertor Heater Head," in Proceedings of 36th Intersociety Energy Conversion Engineering Conference (IECEC), Vol. 1, IECEC2001-CT-33, 2001, pp. 435-440.

4. Halford, G.R., Shah, A., Arya, V.K., Krause, D.L., and Bartolotta, P.A., "Structural Analyses of Stirling Power-Convertor Heater Head for Long-Term Reliability, Durability, and Performance," in proceedings of Space Technology and Applications International Forum (STAIF-2002), edited by M. El-Genk, AIP Conference Proceedings 608, New York, 2002, pp. 880-887.

5. Schreiber, J.G. and Thieme, L.G., "Overview of NASA GRC Stirling Technology Development," in Proceedings of 1st International Energy Conversion Engineering Conference, Portsmouth, VA, Paper No. AIAA-2003-6093, 2003.

6. Shah, A.R., Halford, G.R., Korovaichuk, I., "Reliability-Based Life Assessment of Stirling Convertor Heater Head," in proceedings of Space Technology and Applications International Forum (STAIF2004), edited by M. El-Genk, AIP Conference Proceedings 699, New York, 2004.

7. Thieme, L.G. and Schreiber, J.G., "Supporting Development for the Stirling Radioisotope Generator and Advanced Stirling Technology Development at NASA Glenn," in proceedings of Space Technology and Applications International Forum (STAIF-2005), edited by M. El-Genk, AIP Conference Proceedings 746, New York, 2005, pp. 674-681. 
Public reporting burden for this collection of information is estimated to average 1 hour per response, including the time for reviewing instructions, searching existing data sources, gathering and maintaining the data needed, and completing and reviewing the collection of information. Send comments regarding this burden estimate or any other aspect of this collection of information, including suggestions for reducing this burden, to Washington Headquarters Services, Directorate for Information Operations and Reports, 1215 Jefferson Davis Highway, Suite 1204, Arlington, VA 22202-4302, and to the Office of Management and Budget, Paperwork Reduction Project (0704-0188), Washington, DC 20503.

\begin{tabular}{|l|l|l|}
\hline 1. AGENCY USE ONLY (Leave blank) & $\begin{array}{c}\text { 2. REPORT DATE } \\
\text { April } 2006\end{array}$ & $\begin{array}{r}\text { 3. REPORT TYPE AND DATES COVERED } \\
\text { Technical Memorandum }\end{array}$ \\
\hline
\end{tabular}

\section{TITLE AND SUBTITLE} 5. FUNDING NUMBERS

Accelerated Life Structural Benchmark Testing for a Stirling Convertor Heater Head

\section{AUTHOR(S)}

WBS 138494.04.01.01

David L. Krause and Pete T. Kantzos

\section{PERFORMING ORGANIZATION NAME(S) AND ADDRESS(ES)}

National Aeronautics and Space Administration

John H. Glenn Research Center at Lewis Field

Cleveland, Ohio 44135-3191
8. PERFORMING ORGANIZATION REPORT NUMBER

E-15553

\section{SPONSORING/MONITORING AGENCY NAME(S) AND ADDRESS(ES)}

10. SPONSORING/MONITORING AGENCY REPORT NUMBER

National Aeronautics and Space Administration

Washington, DC 20546-0001
NASA TM-2006-214267

\section{SUPPLEMENTARY NOTES}

Prepared for the Space Technology and Applications International Forum (STAIF-2006) sponsored by the University of New Mexico's Institute for Space and Nuclear Power Studies (UNM-ISNPS), Albuquerque, New Mexico, February 12-16, 2006. David L. Krause, e-mail: krause@nasa.gov, Glenn Research Center; Pete T. Kantzos, Ohio Aerospace Institute, 22800 Cedar Point Road, Brook Park, Ohio 44142. Responsible person, David L. Krause, organization code RXL, 216-433-5465.

12a. DISTRIBUTION/AVAILABILITY STATEMENT 12b. DISTRIBUTION CODE

Unclassified - Unlimited

Subject Category: 26

Available electronically at http://gltrs.grc.nasa.gov

This publication is available from the NASA Center for AeroSpace Information, 301-621-0390.

13. ABSTRACT (Maximum 200 words)

For proposed long-duration NASA Space Science missions, the Department of Energy, Lockheed Martin, Infinia Corporation, and NASA Glenn Research Center are developing a high-efficiency, 110 W Stirling Radioisotope Generator (SRG110). A structurally significant limit state for the SRG110 heater head component is creep deformation induced at high material temperature and low stress level. Conventional investigations of creep behavior adequately rely on experimental results from uniaxial creep specimens, and a wealth of creep data is available for the Inconel 718 material of construction. However, the specified atypical thin heater head material is fine-grained with a heat treatment that limits precipitate growth, and little creep property data for this microstructure is available in the literature. In addition, the geometry and loading conditions apply a multiaxial stress state on the component, far from the conditions of uniaxial testing. For these reasons, an extensive experimental investigation is ongoing to aid in accurately assessing the durability of the SRG110 heater head. This investigation supplements uniaxial creep testing with pneumatic testing of heater headlike pressure vessels at design temperature with stress levels ranging from approximately the design stress to several times that. This paper presents experimental results, post-test microstructural analyses, and conclusions for four higher-stress, accelerated life tests. Analysts are using these results to calibrate deterministic and probabilistic analytical creep models of the SRG110 heater head.

\section{SUBJECT TERMS}

Stirling cycle; mechanical properties; Creep rupture strength; Steady state creep;

Strain rate; Deformation; Life (durability); Pressure vessels; Multiaxial; Nickel alloys; Heat treatment; Microstructure; Precipitates

\begin{tabular}{|c|c|c|}
\hline $\begin{array}{c}\text { 17. SECURITY CLASSIFICATION } \\
\text { OF REPORT } \\
\text { Unclassified }\end{array}$ & $\begin{array}{c}\text { 18. SECURITY CLASSIFICATION } \\
\text { OF THIS PAGE } \\
\text { Unclassified }\end{array}$ & $\begin{array}{c}\text { 19. SECURITY CLASSIFICATION } \\
\text { OF ABSTRACT } \\
\text { Unclassified }\end{array}$
\end{tabular}

\begin{tabular}{|l|} 
15. NUMBER OF PAGES \\
16 \\
\hline 16. PRICE CODE \\
20. LIMITATION OF ABSTRACT \\
\end{tabular}



